\title{
Unusual Limb Deformations of a Cuban Brown Anole, Anolis sagrei (Squamata: Dactyloidae)
}

Luis F. de Armas

P.O. Box 4327, San Antonio de los Baños, Artemisa 38100, Cuba (luisdearmas1945@gmail.com)

$T^{\prime}$

he Cuban Brown Anole (Anolis sagrei Cocteau in Duméril and Bibron 1837) is widely distributed across much of the Cuban Archipelago and is abundant in towns and other anthropogenic areas (Rodríguez-Schettino 1999). It also has established permanent populations in several tropical and subtropical countries, including the southern United
States, eastern Mexico and Central America, other West Indian islands, Hawaii, and Taiwan (Henderson and Powell 2009; Sanz-Ochotorena and Rodriguez-Gomez 2014).

On 6 December 2014, in a residential backyard in San Antonio de los Baños $\left(22^{\circ} 53^{\prime} 36.49^{\prime \prime N}, 82^{\circ} 30^{\prime} 35.21^{\prime \prime W}\right.$; elev. $75 \mathrm{~m}$ asl), Artemisa Province, Cuba, I observed an adult

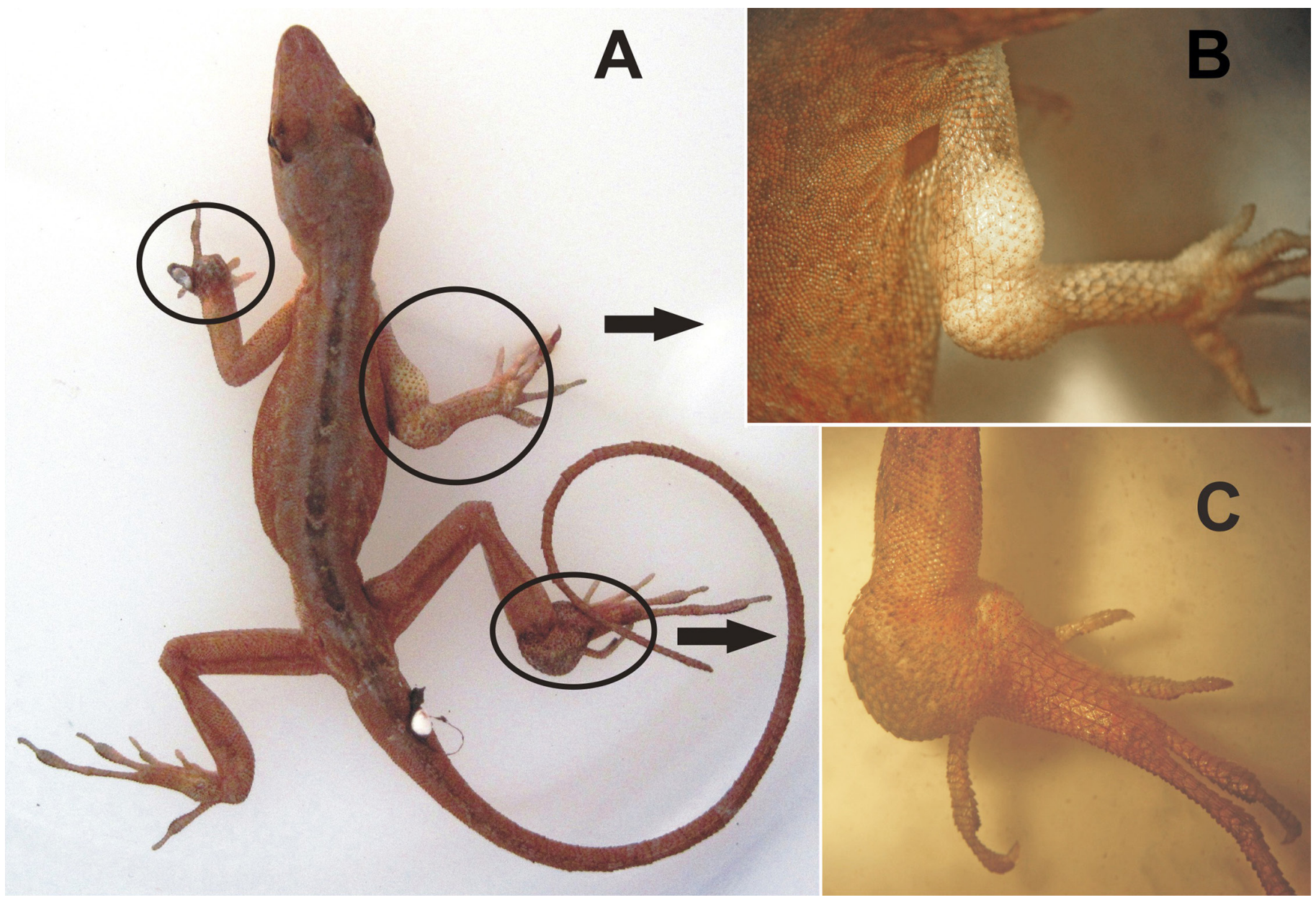

Fig. 1. A female Cuban Brown Anole (Anolis sagrei) from San Antonio de los Baños, Artemisa Province, Cuba, with deformed limbs attributable to tumorlike growths (A); details of the right anterior leg (B) and right posterior leg (C). Photographs by the author. 
female $A$. sagrei that was not moving in the usual fashion. It was easily captured and a quick examination revealed severe tumor-like deformations on the anterior limbs and the right posterior leg (Fig. 1).

I dissected the tumor-like structures searching for a possible parasite (nematodes or dipteran larvae) but found only a whitish viscous liquid. The specimen was not preserved and additional studies on the tumor-like malformations were not conducted.

This is the second known case of tumors in a Cuban anole, and the first for Anolis sagrei. Duran-Reynalds and Clausen (1937) implicated a newly described bacterium as the cause of tumor-like conditions in a Cuban Giant Anole (Anolis equestris).

\section{Acknowledgements}

I thank Manuel Iturriaga (Institute of Ecology and Systematics, Havana, Cuba) for helpful comments on the first version of the manuscript.

\section{Literature Cited}

Duran-Reynalds, F. and H.J. Clausen. 1937. A contagious tumor-like condition in the lizard (Anolis equestris) as induced by a new bacterial species, Serratia anolium (sp. n.). Journal of Bacteriology 33: 369-379.

Henderson, R.W. and R. Powell. 2009. Natural History of West Indian Reptiles and Amphibians. University Press of Florida, Gainesville, Florida.

Rodríguez-Schettino, L. 1999. Systematic accounts of the species, pp. 104-380. In: L. Rodriguez-Schettino (ed.), The Iguanid Lizards of Cuba. University Press of Florida, Gainesville, Florida.

Sanz-Ochotorena, A.C. and Y. Rodríguez-Gómez. 2014. Anolis sagrei (Reptilia: Polychrotinae): exitoso e invasor. Revista Cubana de Ciencias Biológicas 3(1): 15-21. 